\title{
Upaya Peningkatan Pengetahuan Ibu tentang Perawatan Payudara Selama Hamil
}

\author{
Sri Maharani \\ Prodi DIII Kebidanan STIKes Baiturrahim Jambi \\ Email:maharanibarus@gmail.com
}

Submitted :25/11/2019

Accepted: 02/12/2019

Published: 16/06/2020

\begin{abstract}
Breast care during pregnancy is one important part that must be considered as preparation for breastfeeding later. Breasts need to be prepared since pregnancy so that if the baby is born it can function properly immediately when needed. Breast care is also very helpful in the success of early breastfeeding, which affects exclusive breastfeeding. Breast care (Breast Care) is a way of caring for breasts performed during pregnancy or the puerperium for the production of breast milk, other than that for cleanliness of the breast and the form of nipples that go in or flat. Current problems faced by partners include the lack of knowledge of pregnant women regarding the importance of breast care during pregnancy, so it is considered necessary to provide counseling to provide knowledge to pregnant women to prepare pregnant women to give early breastfeeding at the time of delivery and provide exclusive breastfeeding to infants up to 2 years. Community service activities are carried out at the Puskesmas Putri Ayu Kota Jambi. Time of implementation in January 2019. The target is pregnant women. Community service methods survey approach, lecture, discussion, demonstration / simulation. The results obtained are pregnant women able to understand about the benefits of breast care during pregnancy. It is recommended for health workers, especially in Puskesmas to give more information about breast care to pregnant women by participating in activities carried out in the village and RT so that pregnant women get information about breast care and can prepare for early breastfeeding to infants properly.
\end{abstract}

Keywords: breast, nursing, pregnant women

\begin{abstract}
Abstrak
Perawatan payudara pada masa kehamilan adalah salah satu bagian penting yang harus diperhatikan sebagai persiapan untuk menyusui. Payudara perlu dipersiapkan sejak masa kehamilan sehingga bila bayi lahir dapat segera berfungsi dengan baik. Perawatan payudara juga sangat membantu keberhasilan dalam pemberian ASI dini. Perawatan payudara (Breast Care) adalah suatu cara merawat payudara yang dilakukan pada saat kehamilan atau masa nifas. Permasalahan yang dihadapi mitra saat ini antara lain masih kurangnya pengetahuan ibu hamil mengenai pentingnya melakukan perawatan payudara selama kehamilan maka dinilai perlu memberikan penyuluhan untuk memberikan pengetahuan kepada ibu hamil untuk mempersiapkan ibu hamil dalam memberikan asi dini pada saat persalinan dan memberikan asi eksklusif pada bayi sampai dengan 2 tahun. Kegiatan Pengabdian kepada masyarakat ini dilaksanakan di Puskesmas Putri Ayu Kota Jambi. Waktu pelaksanaan pada bulan Januari 2019. Sasaran adalah ibu hamil. Metode pengabdian masyarakat pendekatan survey, ceramah, diskusi, demonstrasi/simulasi. Hasil yang diperoleh adalah ibu hamil mampu memahami tentang manfaat perawatan payudara selama masa kehamilan. Disarankan kepada petugas kesehatan khususnya di Puskesmas agar lebih memberikan penyuluhan tentang perawatan payudara pada ibu hamil dengan ikut serta dalam kegiatan-kegiatan yang dilakukan di kelurahan dan RT sehingga ibu hamil mendapatkan informasi tentang perawatan payudara dan dapat mempersiapkan pemberian ASI dini pada bayi dengan baik.
\end{abstract}

Kata Kunci: ibu hamil, payudara, perawatan 


\section{PENDAHULUAN}

Perawatan payudara bertujuan untuk mengetahui lebih dini adanya kelainan, sehingga diharapkan dapat dikoreksi sebelum persalinan. Pemeriksaan payudara dilaksanakan pada kunjungan pertama ibu dimulai dari inspeksi kemudian palpasi. Pemeriksaan puting susu dilakukan untuk menunjang keberhasilan menyusui, maka pada saat kehamilan puting susu ibu perlu diperiksa kelenturannya dengan cara : sebelum dipegang, periksa dulu bentuk puting susu, cubit areola di sisi puting susu dengan ibu jari dan telunjuk,dengan perlahan puting susu dan areola ditarik. Bila puting susu mudah ditarik,berarti lentur. Tertarik sedikit berarti kurang lentur, masuk ke dalam berarti puting susu terbenam.

Menyusui merupakan awal yang baik dalam kehidupan seorang anak, oleh karena menyusui tidak hanya memenuhi kebutuhan nutrisi, gizi dan antibody pelindung terhadap berbagai infeksi, tetapi anak juga mendapatkan sentuhan, kata-kata, tatapan kasih sayang dan kehangatan yang merupakan hal penting untuk stimulasi dini terhadap tumbuh kembang anak. ASI Eksklusif adalah pemberian ASI saja, termasuk kolostrum tanpa tambahan makanan atau minuman lain sejak bayi lahir, dengan kata lain pemberian susu formula, air matang, air gula, dan madu untuk bayi baru lahir tidak dibenarkan karena asi adalah makanan bayi yang paling penting, terutama pada bulan-bulan pertama kehidupan bayi, menyusui eksklusif diberikan segera setelah bayi lahir sampai usia 6 bulan.

Perawatan payudara pada masa kehamilan adalah salah satu bagian penting yang harus diperhatikan sebagai persiapan untuk menyusui nantinya. Payudara perlu dipersiapkan sejak masa kehamilan sehingga bila bayi lahir dapat segera berfungsi dengan baik pada saat diperlukan.
Perawatan payudara juga sangat membantu keberhasilan dalam pemberian ASI dini, yang mempengaruhi pemberian ASI Eksklusif.

Berdasarkan alasan diatas maka masyarakat terutama ibu hamil khususnya merasa perlu ada wadah yang dapat menampung berbagai permasalahan berkaitan dengan kebutuhan ibu hamil mengenai perawatan payudara, salah satunya dengan kegiatan penyuluhan. Kegiatan ini sebagai wadah menampung permasalahan ibu-ibu hamil dan sebagai tempat bertanya tentang bagaimana melakukan perawatan payudara selama kehamilan untuk mempersiapkan pemberian asi dini pada bayi baru lahir.

\section{TARGET DAN LUARAN}

1. Target

Target dalam kegiatan pengabdian kepada masyarakat ini adalah ibu hamil.

2. Luaran

Adapun luaran kegiatan pengabdian kepada masyarakat ini selain publikasi pada jurnal ilmiah yaitu:

a. Pemahaman ibu hamil tentang perawatan payudara.

b. Serta pemberian kesadaran ibu hamil untuk memberikan ASI eksklusif pada bayi.

\section{METODE PELAKSANAAN}

Kegiatan pengabdian kepada masyarakat dilaksanakan pada bulan Januari 2019 dengan sasaran kegiatan adalah ibu hamil jumlah 10 orang.

Tahapan kegiatan Pengabdian kepada kepada masyarakat meliputi:

\section{Persiapan}

1. Sosialisasi: pertemuan dengan bidan penanggung jawab kelas ibu hamil.

2. Mengidentifikasi masalah.

3. Perumusan solusi : Menyampaikan rencana kegiatan kepada pihak 
puskesmas dengan mengurus surat izi melakkan pengabdian kepada masyarakat.

Pelaksanaan

1. Melakukan pretest (menggali pemahaman ibu hamil tentang perawatan payudara selama kehamilan)

2. Memberikan pendidikan kesehatan tentang perawatan payudara selama kehamilan pada ibu hamil (pengertian, manfaat, cara melakukan, kelemahan).

3. Monitoring dan Evaluasi

\section{HASIL DAN PEMBAHASAN}

Kegiatan penyuluhan ini bertujuan agar ibu hamil memahami tentang perawatan payudara selama kehamilan. Pada pengabdian masyarakat ini dilakukan pendidikan kesehatan kepada ibu hamil mengenai perawatan payudara selama kehamilan. Kegiatan penyuluhan berlangsung kurang lebih 30 menit dan terlaksana dengan tertib dan lancar serta mendapat antusia yang baik dari peserta, maupun puskesmas. Kegiatannya adalah melakukan pendidikan kesehatan berupa penyuluhan tentang perawatan payudara selama masa kehamilan meliputi pengertian, manfaat, cara melakukan, kelemahan. Ibu hamil cukup memahami dan sangat antusias dalam kegiatan ini, terbukti beberapa ibu-ibu bertanya khususnya tentang perawatan payudara.

Perawatan payudara adalah suatu tata laksana yang menyangkut laktasi dan kelancaran ASI, yang menuju keberhasilan menyusui untuk pemeliharaan kesehatan ibu dan bayinya. Perawatan payudara selama kehamilan bertujuan untuk memelihara kebersihan payudara, melenturkan dan menguatkan puting susu yang tertarik kedalam, mempersiapkan produksi ASI.

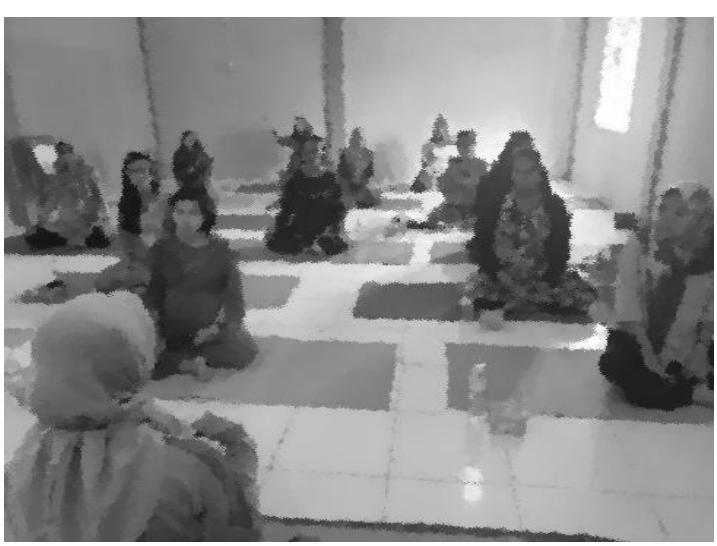

Gambar 1. Penyuluhan kesehatan

Perawatan payudara sebaiknya dilakukan selama masa kehamilan yaitu usia kehamilan setelah delapan bulan (Trimester III) dan bukan sesudah persalinan. Manfaat perawatan payudara selama hamil yaitu menjaga kebersihan payudara terutama kebersihan puting susu, melenturkan dan menguatkan puting susu sehingga memudahkan bayi untuk menyusui, merangsang kelenjar-kelenjar air susu sehingga produksi ASI banyak dan lancar, dan dapat mendeteksi kelainankelainan payudara secara dini dan melakukan upaya untuk mengatasinya. Menyusui merupakan awal yang baik dalam kehidupan seorang anak, oleh karena menyusui tidak hanya memenuhi kebutuhan nutrisi, gizi dan antibody pelindung terhadap berbagai infeksi, tetapi anak juga mendapatkan sentuhan, kata-kata, tatapan kasih sayang dan kehangatan yang merupakan hal penting untuk stimulasi dini terhadap tumbuh kembang anak. ASI Eksklusif adalah pemberian ASI saja, termasuk kolostrum tanpa tambahan makanan atau minuman lain sejak bayi. lahir, dengan kata lain pemberian susu formula, air matang, air gula, dan madu untuk bayi baru lahir tidak dibenarkan karena asi adalah makanan bayi yang paling penting, terutama pada bulan-bulan pertama kehidupan bayi, menyusui eksklusif diberikan segera setelah bayi lahir sampai usia 6 bulan 
Pada akhir evaluasi dilakukan sesi tanya jawab untuk mengetahui sejauhmana pemahaman ibu hamil tentang perawatan payudara.

\section{KESIMPULAN DAN SARAN \\ 1. Kesimpulan}

Pelaksanaan pengabdian kepada mayarakat khususnya ibu hamil di Puskesmas Putri Ayu Kota Jambi yang dilakukan oleh dosen Sekolah Tinggi Ilmu Kesehatan Baiturahim Jambi berjalan dengan baik. Ibu hamil yang hadir antusias dalam membaca leaflet yang diberikan dan bertanya apa yang mereka belum mengerti. Kegiatan ini memberikan pengalaman yang baik kepada ibu hamil untuk melakukan perawatan payudara selama kehamilan untuk persiapan menyusui.

\section{Saran}

Agar lebih sering mengikuti kegiatan yang memberikan pengetahuan bagi ibu dengan menghadiri penyuluhan kesehatan lainnya sehingga dapat meningkatkan pengetahuan ibu.

\section{UCAPAN TERIMAKASIH}

Ucapan terimakasih kami sampaikan kepada Sekolah Tinggi Ilmu Kesehatan Baiturrahim Jambi yang telah memfasilitasi kegiatan ini, dan tak lupa kepada semua pihak yang telah membantu kegiatan kepada masyarakat ini.

\section{DAFTAR PUSTAKA}

Adam SK, Martha DK, Gethruida, BHA. 2016. Perawatan Payudara Pada Masa Kehamilan Dan Pemberian Asi Eksklusif. Jurnal Ilmiah Bidan.Vol:4 N0.2

Alhadar F, Umaternate I. 2017. Pengaruh Perawatan Payudara Pada Ibu Hamil Terhadap Peningkatan Produksi Asi
Di Wilayah Kerja Puskesmas Kota Kecamatan Kota Ternate. Jurnal Riset Kesehatan.6(1)

Klevina MD, Ani KL. Perawatan Payudara pada Ibu Hamil Trimester III dengan Kelancaran ASI pada Post Partum Di RSUD dr. Hardjono Ponorogo. 